\title{
ピリジルチオフェンの電解重合による新しい導電性配位高分子で被覆された炭素粒子の 調製と錯体系酸素還元触媒への応用
}

\author{
小柳津 研一 $* 1 \cdot$ 山口 有朋 $* 2 \cdot$ 井合 雄一 $* 2$ \\ 田中 健 ${ }^{* 2} \cdot$ 湯浅 真 ${ }^{* 1, * 2}$
}

（受付 2005 年 9 月 9 日・審査終了 2005 年 11 月 28 日)

\begin{abstract}
要 旨 電解重合性を有する新しい配位性モノマーとして，2-(3-チエニル)ピリジンを用いた流動層電 解重合により, 配位子としてピリジル基を有する導電性高分子膜で被覆された炭素粒子を調製した。これ を有機溶媒中に分散させ，酶酸コバルトを用いた錯形成を行うことにより，炭素粒子の表面にコバルト錯 体を分散度高く修飾できることを見出した。得られた修飾炭素粒子をNafion 溶液に分散させ，基板電極 上にキャストすることにより擬似 MEA を作製し, 溶存酸素の電解還元反応について検討した. 触媒担体 として比表面積の大きいカーボンブラックを択び，補助的な配位子としてピロールを用いた場合に，貴な 電位 $\left(E_{\mathrm{p}}=0.37 \mathrm{~V} v s . \mathrm{SCE}\right.$ ) 抢よび比較的高い反応選択度 (反応電子数 $n=3.1$ ) で酸素の四電子還元が進行す ることが明らかになった。この活性は, コバルトポリピロール錯体修飾炭素粒子よりも高く, 塩基性度の 高いピリジル基が活性点であるコバルトイオンの集積に寄与していることが示された．さらに，得られた 触媒を不活性ガス雾囲気下で熱処理することにより活性が著しく向上することが分かり, 燃料電池の新し いカソード触媒としての可能性が明らかになった。
\end{abstract}

\section{1 緒言}

固体高分子形燃料電池のカソード電極触媒として現 在，白金系触媒が主に用いられているが1)，白金は高価 でかつ希少な物質であることから代替材料の開発が求 められている.コバルト錯体に関する一連の研究におい て，ポルフィリンなどの窒素ドナ一配位子を含む錯体に 特徵的なコバルト-窒素 $(\mathrm{Co}-\mathrm{N})$ 系平面四配位構造が，酸 素還元反応に有効な活性点となることが報告されてい る2) 17)。これに対し著者らは，炭素粒子表面をポリピ ロールで修飾し，コバルトを配位させることで酸素還元 触媒となることを見いだしている ${ }^{18) \sim 19)}$ 。本研究では， 炭素粒子上に効率高く Co-N 系構造を構築することを目 的として，コバルトに対する配位力が強いピリジンと， 高い導電性を有するチオフェンが結合した2-(3-チエニ ル)ピリジンを炭素粒子上に電解重合し，得られる全共 役系の高分子配位子にコバルトを導入することで触媒の 調製を検討した。

*1 東京理科大学界面科学研究所 (逐162-8601 東京都新宿区 神楽坂 1-3)

*2 東京理科大学理工学部 (画278-8510 野田市山崎2641)

\section{2 実験方法}

\section{1 試薬および溶媒}

2-(3-チエニル)ピリジン $\left(\mathrm{C}_{9} \mathrm{H}_{7} \mathrm{NS}\right)$ は東京化成 (株) 製 を，ピロール $\left(\mathrm{C}_{4} \mathrm{H}_{5} \mathrm{~N}\right)$ は Aldrich（株）製（純度 $98 \%$ )を， 過塩素酸アンモニウム $\left(\mathrm{NH}_{4} \mathrm{ClO}_{4}\right)$ は和光純薬工業(株) 製 (特級, 純度 $98 \%$ )を, 酢酸コバルト $\left(\mathrm{Co}\left(\mathrm{CH}_{3} \mathrm{COOH}\right)_{2}\right)$ は和光純薬工業(株)製 (特級, 純度 $99.0 \%$ ) を, 過塩素酸 $\left(\mathrm{HClO}_{4}\right)$ は和光純薬工業 (株)製 $(60 \%)$ を，塩化鉄 (III) は Aldlich（株）製（純度 97.0\%) を，Nafion は Aldrich (株)製の $5 \mathrm{wt} \%$ 溶液をそれぞれ使用した。炭素粒子は 三菱化学 (株)より供された Ketjen Black EC(粒子径 30 $\mathrm{nm})$ を用いた。

\section{2 測定機器}

電解重合は, 北斗電工 (株)製 HAB-151 装置および理 研電子 F-35CN を用いて行った. IR スペクトルは, 日本 分光 (株) 製 JASCO FT/IR-140 を用いて測定した。 導電 率は共和理研 K-705RS を用いて求めた。触媒活性は日 厚計測 DPGS-1, 北斗電工 HB-104, 理研電子 D-72DG を組み合わせて測定した。微分パルスボルタンメトリー (DPV)は北斗電工 (株) 製 HZ-5000を用いて測定した。 X 線光電子分光スペクトル (XPS) は，島津製作所 (株) 製 AXIS-HI を用いて測定した。 


\subsection{2 -(3-チェニル) ピリジンの重合}

\subsection{1 電解重合}

$10 \mathrm{~mL}$ メスフラスコに過塩素酸アンモニウムと水-メ タノール $(1: 1)$ の混合溶媒を加え, $0.1 \mathrm{M}$ の支持電解質 溶液を調製した。これを電解セルに入れ，モノマーであ る2-(3-チエニル)ピリジンを $1.5 \mathrm{mmol}$ 溶解させた後, 10 分間 $\mathrm{Ar}$ 脱気を行った。 サイクリックボルタモグラム を記録しながら繰り返し電位を掃引することにより，作 用極上に重合膜を形成させた。 また，ITO電極を用い て吸収スペクトルを測定できる半透明の重合膜を形成さ せ，UV-vis スペクトル測定に供した。

\subsection{2 化学酸化重合 ${ }^{20)}$}

四つロフラスコにジクロロメタンを $20 \mathrm{~mL}$, 塩化鉄 (III)を $0.01 \mathrm{~mol}$ 加え, スターラーでかくはんしながら $\mathrm{Ar}$ 脱気を 10 分間行った. 2-(3-チエニル)ピリジンを 2 $\mathrm{mmol}$ 加え, $\mathrm{Ar}$ 脱気を継続しながら一昼夜かくはんし

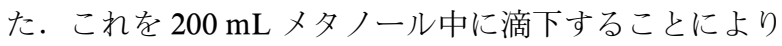
生成ポリマーを分離し, 遠心分離と真空乾燥を経て目的 のポリマーを得た.

\section{4 触媒調製}

\subsection{1 炭素粒子の前処理}

円筒乃紙に炭素粒子を約 $6 \mathrm{~g}$ 入れソックスレー抽出装 置にセットした. 洗浄試薬として, ベンゼンとへキサン を各々 $150 \mathrm{~mL}$ 添加し, 約 6 時間還流条件下で連続的に 洗浄することで前処理を行った.

\subsubsection{2-(3-チエニル)ピリジンの炭素粒子への電解重合} 支持電解質として過塩素酸アンモニウム $(8 \mathrm{mmol})$ を 用い, 溶媒を水/メタノール $(1: 1)$ もくはメタノール (共に $80 \mathrm{~mL}$ ) として $0.1 \mathrm{M}$ の支持電解質溶液を調製し た. 流動層電解セル (Figure 1)の作用極側と対極側に支 持電解質溶液を $40 \mathrm{~mL}$ ずつ加え，作用極側に2-(3-チ工 ニル)ピリジンを $15 \mathrm{mmol}$, 炭素粒子を $0.4 \mathrm{~g}$ 入れた後, 全体を Ar 脱気し，高速でかくはんしながら作用極に $1.7 \mathrm{~V}$ の電位を印加することにより電解重合を行った.

\subsubsection{2-(3-チエニル)ピリジンとピロールの炭素粒子} への混合電解重合

支持電解質として過塩素酸アンモニウムを $8 \mathrm{mmol}$ 用 い，溶媒を水/メタノール $(1: 1)$ もしくはメタノール $(80$ $\mathrm{mL})$ として $0.1 \mathrm{M}$ の支持電解質溶液を調製した。流動 層電解重合セル (Figure 1)の両極にこの支持電解質溶液 を $40 \mathrm{~mL}$ ずつ加え，作用極側にピロールを $15 \mathrm{mmol}$, 2-(3-チエニル)ピリジンを $15 \mathrm{mmol}$ ，炭素粒子を $0.4 \mathrm{~g}$ 添加して $\mathrm{Ar}$ 脱気し，作用極に $1.7 \mathrm{~V}$ の電位を印加する ことにより電解重合を行った.

\section{4 .4 コバルトの導入}

$50 \mathrm{~mL}$ の $N, N$-ジメチルホルムアミド (DMF)を含むナ スフラスコ中に酢酸コバルト $0.1 \mathrm{~g}$ を溶解させ, 2.4.2 項 に示した方法で表面に電解重合膜を形成させた炭素粒子

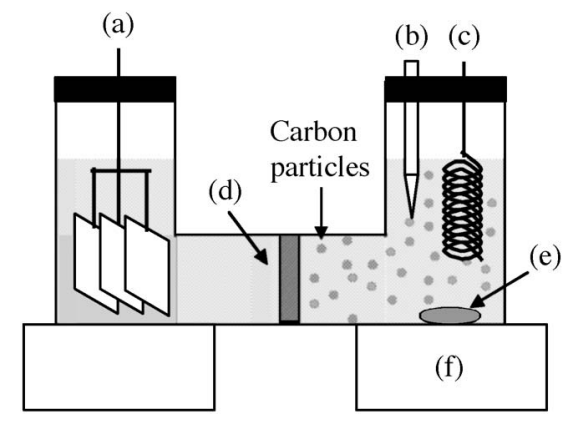

Figure 1. Fluid bed electrolysis apparatus. (a) Stainless Plate (b) $\mathrm{Ag} / \mathrm{AgCl}$ electrode (c) Pt wire (d) sintered glass separating membrane (e) stirring bar (f) Magnetic stirrer.

を加え，超音波照射により分散させた．Ar 脱気(20 分) 後, $\mathrm{Ar}$ 雾囲気を保ちながら還流を 2 時間行った.

\subsection{5 補助配位子添加系の錯形成}

$50 \mathrm{~mL}$ の $N, N$-ジメチルホルムアミド (DMF) を導入し たナスフラスコに酢酸コバルト $0.1 \mathrm{~g}$ ，ピロールまたは ピリジン $(1.6 \mathrm{mmol})$ を溶解させ, 2.4.3 項の方法で電解 重合により表面修飾した炭素粒子を加え, 超音波照射に より分散させた．Ar 脱気を 20 分行い, Ar 雾囲気を保 ちながら還流を 2 時間行うことにより, 同様に錯形成を 行った.

\subsection{6 炭素粒子担持触媒の熱処理 ${ }^{21)}$}

調製した触媒を $\mathrm{Ar}$ ガス雾囲気下で $5^{\circ} \mathrm{C} / \mathrm{min}$ にて昇温 し, 次いで所定の設定温度で 2 時間保持したあと自然放 冷した。

\section{5 触媒の活性評価と構造解析}

得られた触媒の活性は CV により評価した. 反応電子 数 $n$ は, RDE を用いて回転速度を变化させて $(100,200$, 400, 600 抢よび $900 \mathrm{rpm}$ ) 拡散限界電流を求め, Koutecky-Levich プロットの傾きから決定した．この時に用 いた酸素の濃度と拡散係数は, それぞれ $1.5 \times 10^{-3} \mathrm{~mol} / \mathrm{L}$ 抢よび $2.0 \times 10^{-5} \mathrm{~cm}^{2} \mathrm{~s}^{-1}$ とした。 また, 触媒表面の構 造解析はXPSにより行った.

\section{3 結果および考察}

\subsection{2-(3-チエニル)ピリジンの重合}

\subsection{1 電解重合}

作用極としてグラッシーカーボンディスク電極, 対極 として白金線，参照電極として $\mathrm{Ag} / \mathrm{AgCl}$ 電極を用い， 電位範囲を $0 \sim 1.8 \mathrm{~V}$ ，掃引速度を $50 \mathrm{mV} / \mathrm{s}$ として 2-(3チエニル)ピリジンの CV 測定を行ったところ， $1.7 \mathrm{~V}$ 付 近においてモノマーの酸化ピークが見られた (Figure 2). 作用極をITO 電極とした際には, 電極上に茶褐色 の重合膜が形成され，この膜のUV-vis スペクトルで は，チオフェン環に基づく吸収帯がモノマー $\left(\lambda_{\max }=231\right.$ $\mathrm{nm})$ より顕著に長波長シフト $\left(\lambda_{\max }=420 \mathrm{~nm}\right)$ しており, 


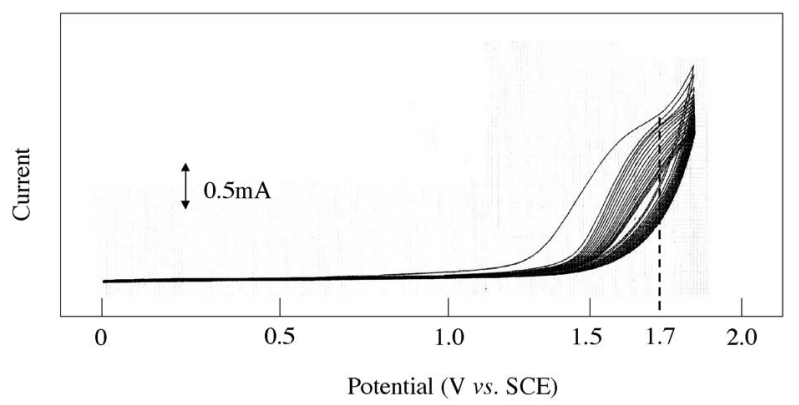

Figure 2. Cyclic voltammogram for the electropolymerization of 2-(3-thienyl) pyridine at a glassy carbon electrode immersed in an electrolyte containing $0.1 \mathrm{M} \mathrm{NH}_{4} \mathrm{ClO}_{4}$ and $\mathrm{H}_{2} \mathrm{O}$ / $\mathrm{MeOH}(1 / 1)$. The monomer concentration was $50 \mathrm{mM}$.

$\pi$ 共役系の発達が認められた。

\subsection{2 化学酸化重合}

2-(3-チエニル)ピリジンの化学酸化重合により, 対応 する重合物が収率 $10 \mathrm{wt} \%$ で得られた。この化合物の IR スペクトルに抢いて，790, 690 抢よび $1180 \mathrm{~cm}^{-1}$ にポリ チオフェンに由来するピークが確認され，1630 $\mathrm{cm}^{-1}$ に ピリジンの $\mathrm{C}=\mathrm{N}$ 環伸縮振動に由来するピークが認めら れた。これらの吸収帯は，重合物であるためブロードで あった。

ポリマーをペレット成型し，四端子法により導電率を 測定したところ, 半導性 $\left(2.9 \times 10^{-5} \mathrm{~S} / \mathrm{cm}\right)$ を示すことが わかった．無置換のポリチオフェンに比べ収率，導電率 がともに低い値となったのは，重合する際にチオフェン の 3 位ピリジル基が立体障害となって重合性が低下して いるためと考えられる.

3.2 触媒の活性評価とキャラクタリゼーション

3.2 .1 コバルトポリピリジルチオフェン錯体触媒 (Co-P3PyTh-C)の活性評価

2-(3-チエニル)ピリジンの電解重合およびコバルト 導入反応により得られた触媒の活性を CV により評価し たところ, 酸素還元波のピーク電位が $E_{\mathrm{p}}=-0.37 \mathrm{~V} v s$. SCE（Figure 3）となり, 触媒活性を示すことが明らかに なった．しかし，この触媒はコバルトポリピロール錯体 修飾炭素粒子19) よりも著しく低活性であった。この原因 として，炭素粒子上に活性点となるコバルトポリピリジ ルチオフェン錯体が少ないことや，ピリジル基の塩基性 度が高いためコバルトが 6 配位錯体を形成して活性点と して寄与しないことなどが考えられる。しかし，XPS により表面分析を行ったところ (Figure 4)，活性に関与 しうるコバルト原子濃度は $0.19 \%$ であり，コバルトポ リピロール錯体修飾炭素粒子に存在するコバルト（原子 濃度 $0.08 \%$ ）と同等以上であることが分かった．触媒未 修飾の炭素粒子やポリピリジルチオフェンのみを修飾し た炭素粒子は酸素還元ピークを示さないことから，コバ

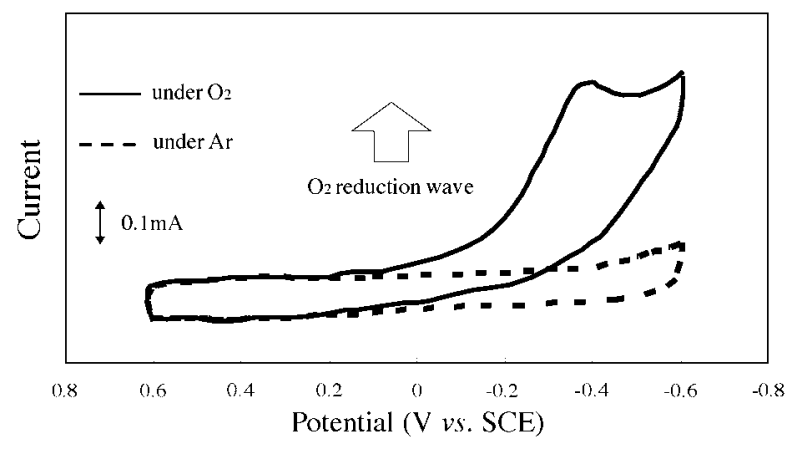

Figure 3. Cyclic voltammogram for the reduction of $\mathrm{O}_{2}$ at edge-plane pyrolytic graphite electrodes $\left(0.28 \mathrm{~cm}^{2}\right)$ coated with a Nafion film containing the Co-P3PyTh-C catalyst.

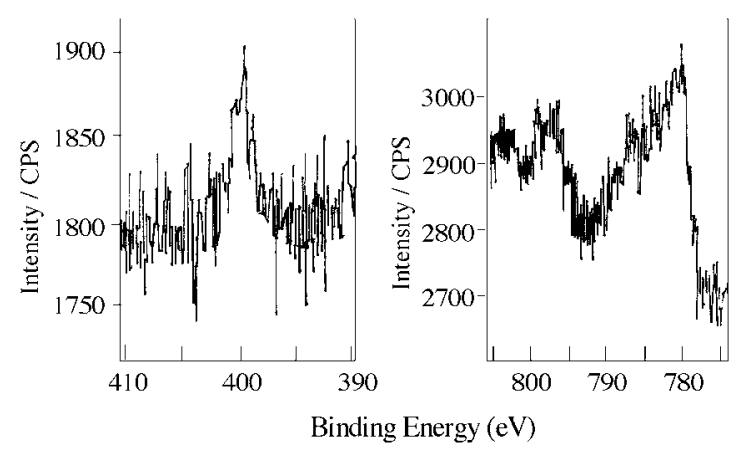

Figure 4. XPS narrow-scan spectra for Co $2 \mathrm{p}^{3 / 2}$ (a) and N $1 \mathrm{~s}$ (b) for the Co-P3PyTh-C catalyst.

ルトが触媒活性点として働いていることは明らかである ので，コバルトポリピリジルチオフェン錯体修飾炭素粒 子の低活性の理由は, 配位子置換不活性で配位飽和型の 6 配位錯体を形成することによる不活性化であると考元 られる。

\subsection{2 混合電解重合型コバルト錯体触媒 (Co-P3PyTh + PPy-C)の活性評価}

2-(3-チエニル)ピリジンとピロールの混合電解重合と コバルトの導入により得られた触媒の活性を CV により 評価したところ, ピーク電位 $E_{\mathrm{p}}=0.06 \mathrm{~V} v s$. SCE で酸 素還元が進行し，2-(3-チエニル)ピリジン単独で電解重 合を行って調製した触媒に比べ，高活性であることがわ かった. XPS スペクトル(Figure 5)より, 窒素原子濃度 は $0.72 \%$, コバルト原子濃度は $0.80 \%$ となり, ポリピ リジルチオフェンのみを修飾した触媒より錯体部が多く

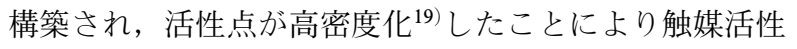
が向上したものと考えられる。

3.2.3 補助配位子添加コバルトポリピリジルチオ フェン錯体触媒 (Co-P3PyTh + PPy-C (ピロー ル添加))の活性評価

2-(3-チエニル)ピリジンの電解重合に続いてピロール やピリジンなどの補助配位子を添加し, 次いでコバルト 


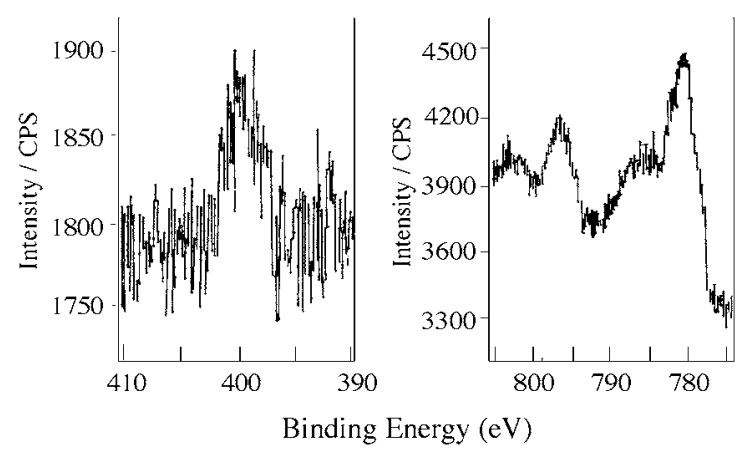

Figure 5. XPS narrow-scan spectra for Co $2 \mathrm{p}^{3 / 2}$ (a) and $\mathrm{N} 1 \mathrm{~s}$ (b) for the Co-P3PyTh + PPy-C catalyst.

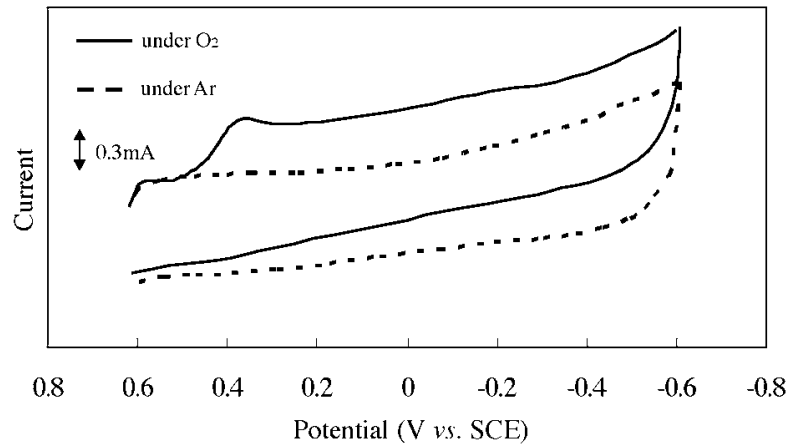

Figure 6. Cyclic voltammogram for the reduction of $\mathrm{O}_{2}$ at edge-plane pyrolytic graphite electrodes coated with a Nafion film containing the Co-P3PyTh-C catalyst with pyrrole as the complementary ligand.

を導入して得られた触媒の活性を CV および RDEによ り評価した。ピリジンを補助配位子として添加した場 合, ピーク電位 $E_{\mathrm{p}}=-0.34 \mathrm{~V} v \mathrm{~s} . \mathrm{SCE}$ で酸素還元が進 行する低活性な触媒であったが，ピロールを添加した場 合は $E_{\mathrm{p}}=0.35 \mathrm{~V} v s . \mathrm{SCE}$ (Figure 6) まで活性が向上し た．Figure 7 の RDE 曲線より Koutecky-Levich プロッ 卜 (Figure 8) を作成し，この直線の傾きから反応電子数 $n$ を求めたところ(詳細は実験項を参照)， $n=3.0$ とな り, 二電子還元だけでなく一部四電子還元反応が進行す ることが明らかになった。この活性向上が添加したピ ロールのみによるものでないことは，コントロール実験 として，ポリピリジルチオフェン未修飾の炭素粒子にピ ロールを吸着させ，次いでコバルトを導入した触媒を用 いて確かめた。その結果, 酸素還元のピーク電位は $E_{\mathrm{p}}$ $=0.21 \mathrm{~V} v s$. SCE まで低下し(Figure 9), ポリピリジル チオフェンとピロールが共に配位子となってコバルトと 錯形成し Co-N 系構造を形成することが活性発現に必要 であることが示された(Figure 10)。また，この触媒の DPV 測定を行ったところ， $0.23 \mathrm{~V} v s . \mathrm{Ag} / \mathrm{AgCl}$ にコバ ルトの二価/三価に由来するピークが観測され，レドッ クス活性点として働いていることが確認された.

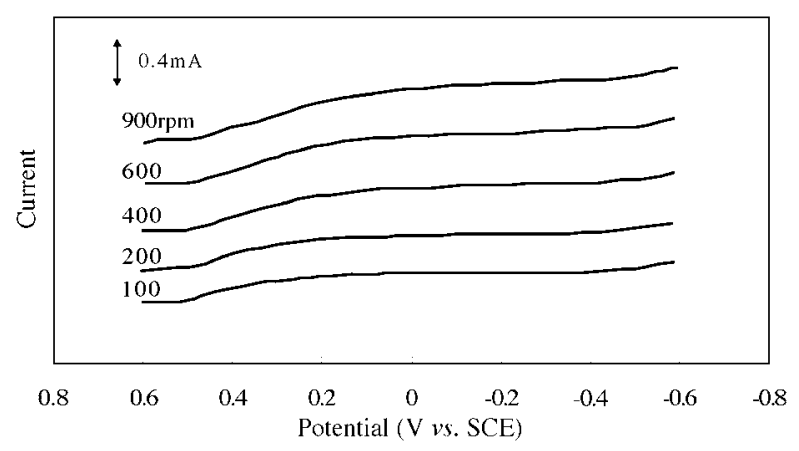

Figure 7. Current-potential responses for the reduction of $\mathrm{O}_{2}$ at electrodes in Figure 6 operated as rotating disk electrodes under $\mathrm{O}_{2}$. Electrode rotation rates were $\omega=100,200,400,600$, and $900 \mathrm{rpm}$.

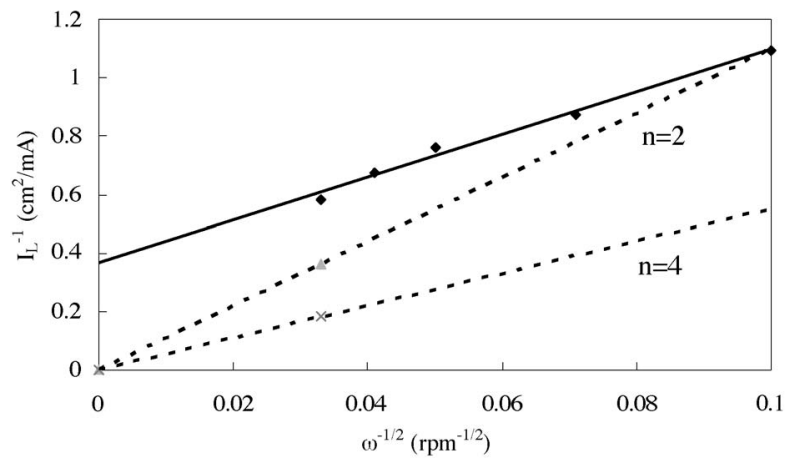

Figure 8. Koutecky-Levich plots of [plateau current $]^{-1}$ vs. $\omega^{-1 / 2}$ in Figure 7.

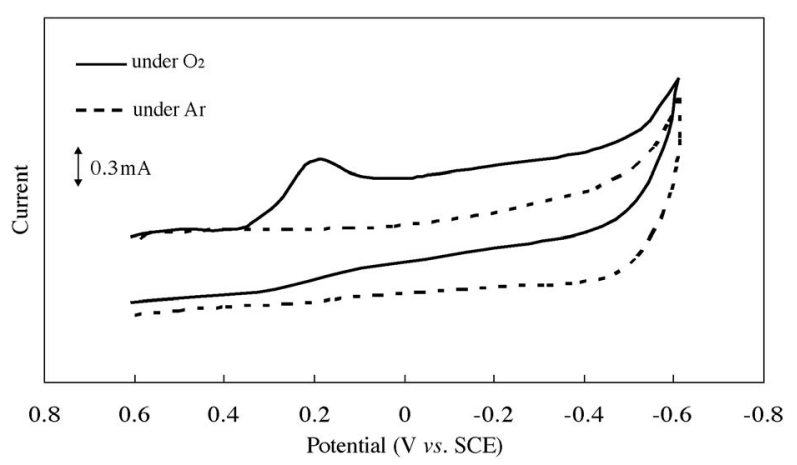

Figure 9. Cyclic voltammogram for the reduction of $\mathrm{O}_{2}$ at edge-plane pyrolytic graphite electrodes coated with the Nafion film containing the Co-P3PyTh $+\mathrm{PPy}-\mathrm{C}$ catalyst.

3.2.4 混合電解重合型高分子配位子に補助配位子を 添加したコバルトポリピリジルチオフェン錯 体触媒 (Co-P3PyTh + PPy-C (ピロール添加) ) の活性評価

さらなる活性向上を期待して，2-(3-チエニル)ピリジ ンとピロールの混合電解重合系に補助配位子としてピ ロールを添加した系について, コバルト導入を行うこと 


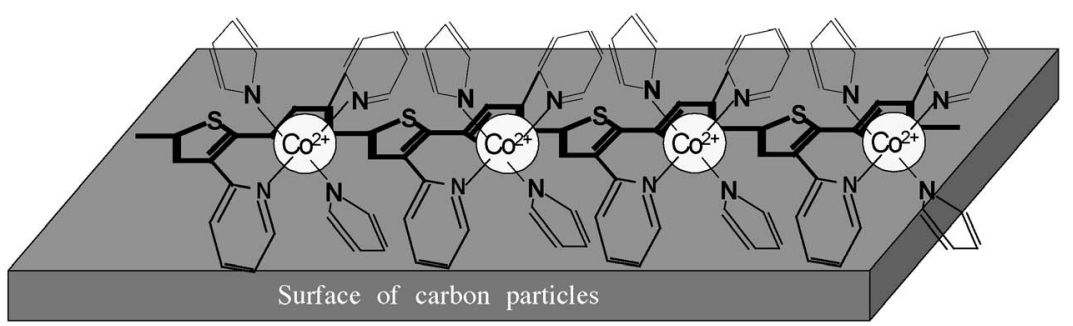

Figure 10. Schematic representation of the Co-P3PyTh-C catalyst containing pyrrole as the complementary ligand.

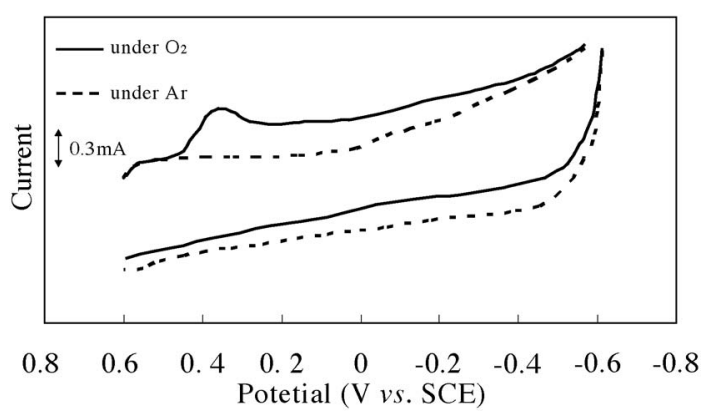

Figure 11. Cyclic voltammogram for the reduction of $\mathrm{O}_{2}$ at edge-plane pyrolytic graphite electrodes coated with a Nafion film the containing the Co-P3PyTh + PPy-C catalyst with pyrrole as the complementary ligand.

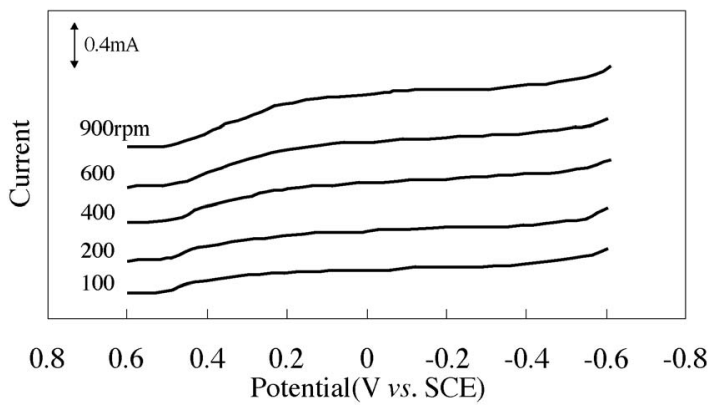

Figure 12. Current-potential responses for the reduction of $\mathrm{O}_{2}$ at electrodes in Figure 10 operated as rotating disk electrodes under $\mathrm{O}_{2}$. Electrode rotation rates were $\omega=100,200$, 400, 600 and $900 \mathrm{rpm}$.

で触媒の調製を行い，CV および RDEにより活性評価 を行った。この場合, 酸素還元のピーク電位は $E_{\mathrm{p}}=$ $0.37 \mathrm{~V}$ vs. SCE (Figure 11) となり, 最も高い活性が発 現することが明らかになった．Figure 12 の RDE曲線 より Koutecky-Levich プロット(Figure 13)を作成し反応 電子数を求めたところ, $n=3.1$ となり, 一連の調製法 の中で最も高い四電子還元の選択度が達成され，四電子 還元反応がかなり優先的に進行する触媒系が得られた. この場合も DPV 測定においてアルゴン下で $0.28 \mathrm{~V} v s$. $\mathrm{Ag} / \mathrm{AgCl}$ にコバルト二価/三価由来のピークが観測さ

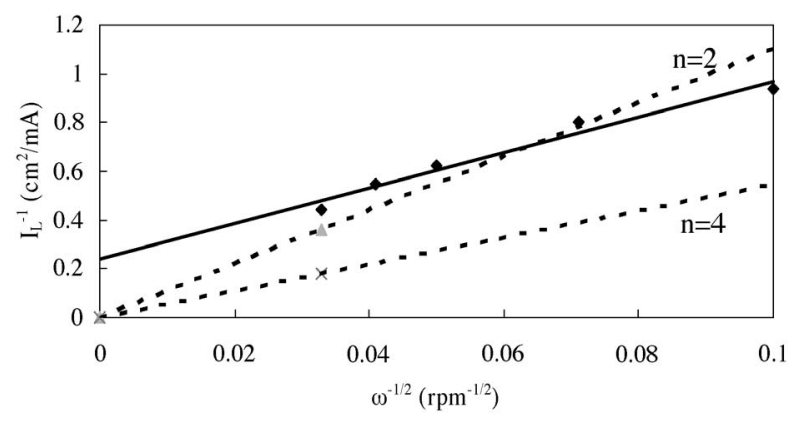

Figure 13. Koutecky-Levich plots of [plateau current $]^{-1}$ vs. $\omega^{-1 / 2}$ in Figure 12 .

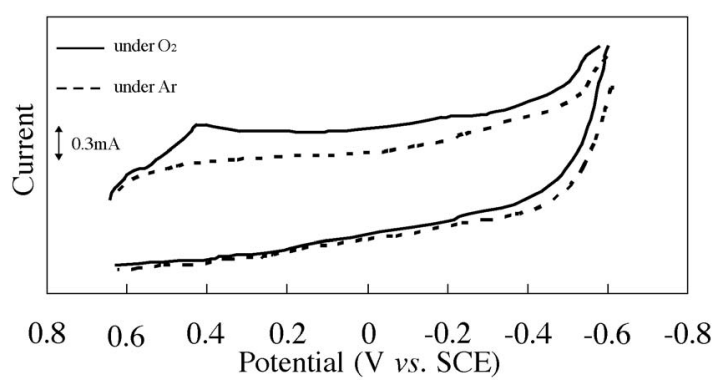

Figure 14. Cyclic voltammogram for the reduction of $\mathrm{O}_{2}$ at edge-plane pyrolytic graphite electrodes coated with a Nafion film containing the HT600-Co-P3PyTh + PPy-C catalyst with pyrrole as the complementary ligand.

れ，同様にレドックス触媒として働いていることが確認 された。

\subsection{5 熱処理による活性向上}

3.2.4 項で調製した触媒について熱処理を行うことで， 活性点を高密度化 ${ }^{19)}$ させた. 熱処理温度を系統的に変化 させて検討したところ, $600^{\circ} \mathrm{C} て ゙$ 熱処理を行った場合に 酸素還元のピーク電位が $E_{\mathrm{p}}=0.43 \mathrm{~V} v s . \mathrm{SCE}$, 反応電子 数 $n=3.4$ となり (Figure 12 および Figure 13), 熱処理 後に触媒活性が大きく向上することがわかった．DPV 測定により $0.38 \mathrm{~V} v$. $\mathrm{Ag} / \mathrm{AgCl}$ にコバルトの二価/三価 に由来するピークが観測され, 熱処理後もレドックス活 性点が残っていることが確認された。 


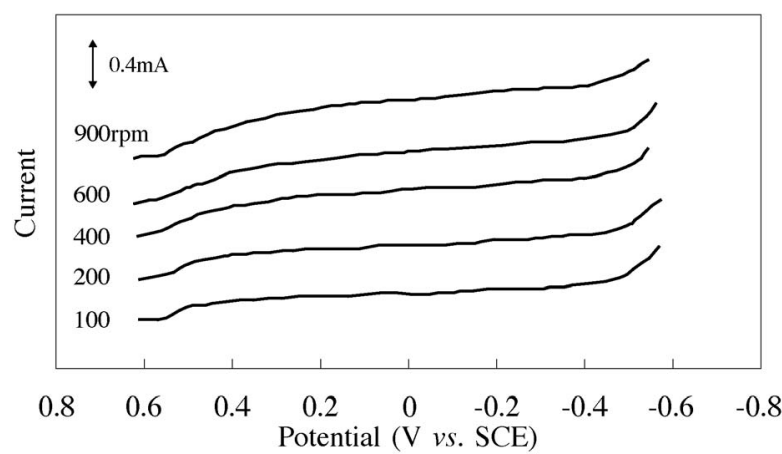

Figure 15. Current-potential responses for the reduction of $\mathrm{O}_{2}$ at electrodes in Figure 12 operated as rotating disk electrodes under $\mathrm{O}_{2}$. Electrode rotation rates were $\omega=100,200$, 400, 600 and $900 \mathrm{rpm}$.

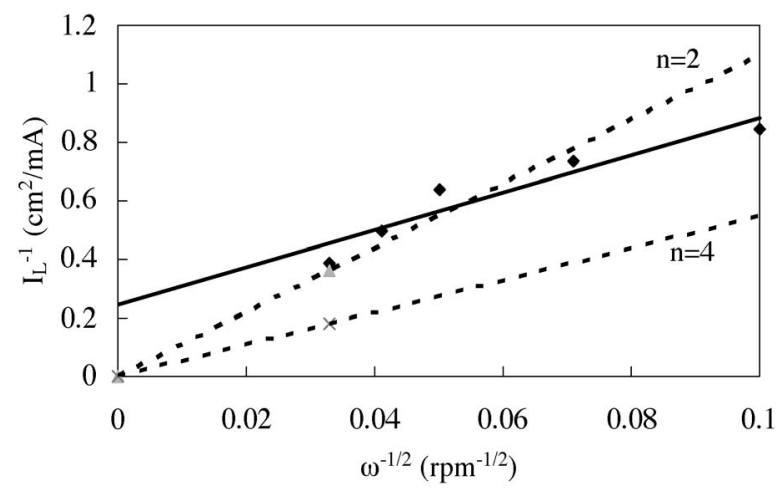

Figure 16. Koutecky-Levich plots of [plateau current $]^{-1} v s$. $\omega^{-1 / 2}$ in Figure 15 .

\section{4 結 論}

電解重合性を有する新しい配位性モノマーとして，2(3-チエニル)ピリジンを用いた流動層電解重合により, ピリジル配位基を有する導電性高分子膜で被覆された炭 素粒子を調製した．酢酸コバルトを用いて錯形成を行う ことにより，炭素粒子の表面にコバルト錯体を分散度高 く修飾できることを見出し，かつ酸素還元活性を示すこ とを実証した。このような錯体が触媒活性点として存在 することにより，未修飾の炭素粒子やコバルトフリーの ポリマーで修飾された炭素粒子を介した酸素還元系に比 べ，小さな過電圧で反応が進行することが確認された。 活性向上を可能とする第一の方法として，2-(3-チエニ ル)ピリジンとピロールを混合して流動層電解重合を行 うことにより(混合電解重合法)，2-(3-チエニル)ピリジ ン単独で調製した触媒より高い酸素還元電位 $\left(E_{\mathrm{p}}=0.06\right.$ V vs. SCE)を示すことが明らかになった。 また，第二 の方法として, 還流時に補助的な配位子であるピロール
を添加することにより調製した(補助配位子添加法)場 合, さらに高い電位 $\left(E_{\mathrm{p}}=0.35 \mathrm{~V} v s . \mathrm{SCE}\right)$ と反応選択度 (反応電子数 $n=3.0$ ) で酸素四電子還元が進行すること が判明した.この活性は, 従来のコバルトポリピロール 錯体修飾炭素粒子 ${ }^{19)}$ よりも高く, 塩基性度の高いピリジ ル基が活性点であるコバルトイオンの集積に寄与してい ることが示された。これら二つの方法を組み合せて触媒 を調製することにより，さらなる高電位 $\left(E_{\mathrm{p}}=0.37 \mathrm{~V} v \mathrm{~s}\right.$. $\mathrm{SCE}$ ) と反応選択度 (反応電子数 $n=3.1$ ) が達成され, 特 に熱処理後は酸素還元電位 $E_{\mathrm{p}}=0.43 \mathrm{~V} v s$. SCE, 反応電 子数 $n=3.4$ となり, 燃料電池の新しいカソード触媒と しての可能性が明らかになった.

\section{文献}

1）湯浅 真, “図解燃料電池のすべて”, 本間玩也監修, 工業 調查会, 東京 (2003), pp. 104-107.

2) J. P. Collman, P. Denisevich, Y. Konai, M. Marrocco, C. Koval, and F. C. Anson, J. Am. Chem. Soc., 102, 6027 (1980).

3) R. R. Durand Jr., C. S. Bencosme, J. P. Collman, and F. C. Anson, J. Am. Chem. Soc., 105, 2710 (1983).

4) R. R. Durand Jr. and F. C. Anson, J. Electroanal. Chem., 105, 273 (1982).

5) C. K. Chang, H. Y. Liu, and I. Abdalmuhdi, J. Am. Chem. Soc., 106, 2725 (1984).

6) C.-L. Ni, I. Abdalmuhdi, C. K. Chang, and F. C. Anson, J. Phys. Chem., 91, 1158 (1987).

7) C. J. Chang, Y. Deng, A. F. Heyduk, C. K. Chang, and D. G. Nocera, Inorg. Chem., 39, 959 (2000).

8) C. J. Chang, Y. Deng, S.-M. Peng, G.-H. Lee, C. Y. Yeh, and D. G. Nocera, Inorg. Chem., 41, 3008 (2002).

9) L. L. Chang, C. J. Chang, and D. G. Nocera, J. Org. Chem., 68, 4075 (2003).

10) C. J. Chang, Y. Deng, C. Shi, C. K. Chang, F. C. Anson, and D. G. Nocera, Chem. Commun., 2000, 1355.

11) Y. Deng, C. J. Chang, and D. G. Nocera, J. Am. Chem. Soc., 122, 410 (2000).

12) C. J. Chang, Z.-H. Loh, Y. Deng, and D. G. Nocera, Inorg. Chem., 42, 8262 (2003).

13) C. J. Chang, Z.-H. Loh, C. Shi, F. C. Anson, and D. G. Nocera, J. Am. Chem. Soc., 126, 10013 (2004).

14) Z.-H. Loh, S. E. Miller, C. J. Chang, S. D. Carpenter, and D. G. Nocera, J. Phys. Chem. A, 106, 11700 (2002).

15) C. J. Chang, E. A. Barker, B. J. Pistorio, Y. Deng, Z.-H. Loh, and D. G. Nocera, Inorg. Chem., 41, 3102 (2002).

16) J. M. Hodgkiss, C. J. Chang, B. J. Pistorio, and D. G. Nocera, Inorg. Chem., 42, 8270 (2003).

17) B. J. Pistorio, C. J. Chang, and D. G. Nocera, J. Am. Chem. Soc., 124, 7884 (2002).

18）小柳津研一, 湯浅 真, 膜, 30, 254 (2005).

19) M. Yuasa, A. Yamaguchi, H. Itsuki, K. Tanaka, M. Yamamoto, and K. Oyaizu, Chem. Mater., 17, 4278 (2005).

20) F. Martinez, J. Retuert, and G. Neculqueo, Int. J. Polym. Mater., 28, 51 (1995).

21) A. J. Bouwkamp and W. Visscher, Electrochim. Acta, 45, 379 (1999). 
Preparation of Novel Conductive Polymer Ligand-Coated Carbon Particles by Electropolymerization of Pyridylthiophene and Application as Metal Complex Catalysts for Oxygen Reduction

Kenichi OYaIzU ${ }^{* 1}$, Aritomo YamaGuchi ${ }^{* 2}$, Yuichi IAI ${ }^{* 2}$, Ken TANAKA ${ }^{* 2}$, and Makoto YuASA ${ }^{* 1, * 2}$

${ }^{* 1}$ Institute of Colloid and Interface Science, Tokyo University of Science (Kagurazaka, Shinjuku-ku, Tokyo 162-8601, Japan)

${ }^{* 2}$ Department of Pure and Applied Chemistry, Faculty of Science and Technology, Tokyo University of Science (Yamazaki, Noda, Chiba 278-8510, Japan)

Conductive polymer ligand-coated carbon particles were prepared by a fluid-bed electrolysis of 2-(3-pyridyl)thiophene using carbon particles as a working electrode. The resulting particles were suspeneded in a DMF solution of cobalt acetate. The surface of carbon particles was successfully modified with the highly dispersed cobalt complex. The modified carbon particles were suspended in an alcoholic solution of Nafion, and a pseudo-MEA was prepared on an electrode by casting the solution. The electrocatalytic reduction of dissolved $\mathrm{O}_{2}$ was examined using the modified electrode. When the catalyst was prepared using a carbon black with a large surface area and pyrrole was added as a complementary ligand, the catalytic potential for the reduction of $\mathrm{O}_{2}$ appeared at $E_{\mathrm{p}}=0.37 \mathrm{~V} v s$. SCE. The catalyst was found to reduce $\mathrm{O}_{2}$ mainly with four electrons $(n=3.1)$. This activity was superior to that of the previously reported carbon nanoparticles modified with a cobalt polypyrrole complex. It was clearly shown that nitrogen atoms of the pyridine-type ligand contribute to accumulate cobalt ions on the surface of the catalyst. It was also revealed that the catalytic activity improved remarkably after heat treatment of the catalyst under argon. The catalyst revealed the possibility of its use as a cathode catalyst for platinum-free fuel cells.

KEY WORDS Poly (pyridylthiophene) / Oxygen reduction / Electropolymerization / Electrocatalyst /

(Received September 9, 2005: Accepted November 28, 2005)

[Kobunshi Ronbunshu, 63(3), 189-195 (2006)] 